\title{
Treatment of bipolar mania with paliperidone extended-release
}

\author{
Paraskevi Kotorki ${ }^{*}$, Christina Leotsakou ${ }^{2}$, Parthena Pelka ${ }^{2}$, Christos Labiris ${ }^{2}$, Efthymia Mantzari ${ }^{2}$, \\ Aikaterini Messinezi ${ }^{2}$, Markella Fiste ${ }^{2}$, Periklis Paterakis ${ }^{2}$ \\ From $1^{\text {st }}$ International Congress on Neurobiology and Clinical Psychopharmacology and European \\ Psychiatric Association Conference on Treatment Guidance \\ Thessaloniki, Greece. 19-22 November 2009
}

\section{Background}

Bipolar disorder is a life-long condition associated with frequent relapses of symptoms and clinicians often use combinations of psychotropic agents to treat their patients. Second generation antipsychotics are a frequent choice in antimanic pharmacologic treatment. The evidence suggests that for acute mania a combination of lithium or valproate and an atypical antipsychotic is the most effective approach. Paliperidone extended-release (ER) is approved for treatment of acute schizophrenia and for maintenance treatment of schizophrenia. It has - probably as a result of its pharmacokinetic profileshown robust efficacy, and a favorable tolerability in multiple trials for the treatment of schizophrenia. Our goal was to assess its efficacy and tolerability as acute and maintenance of effect therapy in patients with bipolar I disorder experiencing manic or mixed episodes while on a mood stabilizer.

\section{Materials and methods}

Six hospitalized patients ( 2 men and 4 women) with average age 35.6 years and average duration of illness 7.2 years, with acute bipolar I mania ( 2 of them with a mixed episode) were put on paliperidone (3 patients on $6 \mathrm{mg}$ and 3 patients on $9 \mathrm{mg}$ ). They were all receiving a mood stabilizer ( 3 were on valproate, 2 on lithium, and one on topiramate) although compliance was partial in at least 4 of the cases. The primary outcome measure was the mean change in the Young Mania Rating Scale (at baseline average: 40,3) and secondary measures included the 21-item Hamilton Rating Scale for Depression (HAM-D-21) and Clinical Global Impressions-Bipolar Version [(CGI-BP), at baseline average: 5,4] at Week

${ }^{1}$ Social Insurance Institue, Analipsi, Thessaloniki, Greece
4 (average YMRS: 14 and CGI-BP: 3), 8 (average YMRS: 11 and CGI-BP: 2,4), and 16(average YMRS: 11 and CGI-BP: 2,2).

\section{Results}

Paliperidone ER provided improvement of acute mania within 4 days, continuing over 4 weeks and sustained over 16 weeks in 5 of our 6 patients. It was discontinued in one at day 8 due to worsening of her symptoms. Paliperidone was generally well tolerated and helped patients achieve and maintain remission without occurrence of depressive symptoms. In 2 of the patients on $9 \mathrm{mg}$, paliperidone was lowered to $6 \mathrm{mg}$ after 8 weeks without recurrence of symptoms. No patient developed major depression.

\section{Conclusions}

Well tolerated and effective therapies for bipolar mania are required. It is well known that patients with bipolar disorder appear more sensitive to antipsychotics. Paliperidone provided in our small sample significant improvement of acute mania and maintained its effect for 4 months. Paliperidone ER may be a safe and effective treatment option for acute mania and provide additional benefit over monotherapy for the management of the manic phase but also for control of mood symptoms in the long run, particularly in preventing manic relapses. It should be noticed that our patients suffered moderate to severe manic episodes, 4 of them with psychotic features (Patients 1, 2, 4,6), and had to be hospitalized for them. This could partially explain why the addition of an antipsychotic improved rapidly their symptomatology. Studies with exclusively nonpsychotic acute or mixed episodes should be conducted. 


\section{Author details}

${ }^{1}$ Social Insurance Institue, Analipsi, Thessaloniki, Greece. ${ }^{2} 1$ st and 5th

Department, Dromokaition Psychiatric Hospital, Athens, Greece.

Published: 22 April 2010

\section{References}

1. Marino J, Caballero J: Paliperidone extended-release for the treatment of schizophrenia. Pharmacotherapy 2008, 28(10):1283-98.

2. Perlis RH, Baker RW, Zarate CAJR, Brown EB, Schuh LM, Jamal HH, Tohen M: Olanzapine versus risperidone in the treatment of manic or mixed states in bipolar I disorder: a randomized, double-blind trial. J Clin Psychiatry 2006, 67(11):1747-53.

3. Corena-McLeod Mdel P, Oliveros A, Charlesworth C, Madden B, Liang YQ, Boules M, Shaw A, Williams K, Richelson E: Paliperidone as a mood stabilizer: a pre-frontal cortex synaptoneurosomal proteomics comparison with lithium and valproic acid after chronic treatment reveals similarities in protein expression. Brain Res 2008, 1233:8-19.

4. Young AH, Oren DA, Lowy A, McQuade RD, Marcus RN, Carson WH, Spiller NH, Torbeyns AF, Sanchez R: Aripiprazole monotherapy in acute mania: 12-week randomized placebo- and haloperidol-controlled study. Br J Psychiatry 2009, 194(1):40-8.

doi:10.1186/1744-859X-9-S1-S134

Cite this article as: Kotorki et al.: Treatment of bipolar mania with paliperidone extended-release. Annals of General Psychiatry 2010 9(Suppl 1):S134.

\section{Submit your next manuscript to BioMed Central} and take full advantage of:

- Convenient online submission

- Thorough peer review

- No space constraints or color figure charges

- Immediate publication on acceptance

- Inclusion in PubMed, CAS, Scopus and Google Scholar

- Research which is freely available for redistribution

Submit your manuscript at www.biomedcentral.com/submit 